\title{
Gebelikte Sigara Kullanımının Algılanan Sosyal Destek, Benlik Saygısı ve Psikolojik Sağlamlık ile ilişkisi
}

\author{
The Relationship Between Smoking During Pregnancy and Perceived \\ Social Support, Self-Esteem and Psychological Resilience
}

\author{
Hacer Yalnız Dilcen 1(D), Ayfer Öztürk 2(D), Melike Nebioğlu Yıldız ${ }^{3 \text { (D) }}$ \\ 1. Bartın Üniversitesi, Sağlık Bilimleri Fakültesi, Ebelik Bölümü, Bartın, Türkiye \\ 2. Bartın Üniversitesi, Sağık Bilimleri Fakültesi, Hemşirelik Bölümü, Psikiyatri Hemşireliği Anabilim Dalı, Bartın, Türkiye \\ 3. Mersin Üniversitesi, Tıp Fakültesi, Ruh Sağlığı ve Hastalıkları Anabilim Dalı, Mersin, Türkiye
}

\section{Abstract}

Objective: The aim of this study was to examine the relationship between the perceived social support, self-esteem and psychological resilience of pregnant women who smoke, according to various factors.

Method: A total of 187 literate pregnant women over 18 years old who completed their 13th week, and agreed to participate were included in the study. Sociodemographic data form , Fagerström Nicotine Dependence Test, Rosenberg Self-Esteem Scale, Multidimensional Scale of Perceived Social Support, and Brief Psychological Resilience Scale were used in the study.

Results: It was determined that $13 \%$ of them smoked in their current pregnancy. A statistically significant, positive and weak relationship was found between the perceived social support and self-esteem in pregnant women. When the addiction levels of pregnant women and their perceived social support scores were examined, the model was found to be statistically significant in term of the level of predicting self-esteem of pregnant women.

Conclusion: Considering the possibility of transferring smoking addiction to future generations, prevention of smoking and passive smoking in all individuals, especially expectant mothers, should be considered as one of the important responsibilities of healthcare professionals and the society. It is especially important for healthcare professionals to provide awareness training on this issue.

Keywords: Pregnancy, smooking, perceived social support, self-esteem, psychological resilience

Öz

Amaç: Bu çalışmada, temel olarak sigara kullanımı olan gebelerin algıladıkları sosyal destek, psikolojik dayanıklılık ve benlik saygısı ile iliş̧kisinin çeşitli faktörlere göre incelenmesi amaçlanmıştır.

Yöntem: Çalışmaya 13. gebelik haftasını tamamlayan, okuma ve yazması olan, 18 yaşından büyük ve çalışmaya katılmayı kabul eden 187 gebe araştırmaya dahil edildi. Çalışmada Sosyodemografik Özellikleri Belirlemeye Yönelik Anket Formu , Fagerström Nikotin Bağımlılık Testi, Rosenberg Benlik Saygısı Ölçeği, Çok Boyutlu Algılanan Sosyal Destek Ölçeği, Kısa Psikolojik Sağlamlık Ölçeği kullanıldı.

Bulgular: Araştırmaya katılan gebelerin \%13'ünün şu anki gebeliklerinde sigara içtiği belirlendi. Gebelerin algıladığı sosyal destek ile benlik saygısı arasında istatistiksel olarak anlamlı, pozitif yönlü ve zayıf düzeyde bir ilişki olduğu tespit edildi. Gebelerin bağımlıık düzeyleri ve algıladıkları sosyal destek puanlarının gebelerin benlik saygısını yordama düzeyi incelendiğinde modelin istatistiksel olarak anlamlı olduğu saptandı.

Sonuç: Sigara bağımlıı̆ın gelecek nesillere aktarııması gibi olasılıklar da göz önüne alındığında, sigara kullanımının ve pasif içiciliğin bütün bireylerde özellikle de anne adaylarında önlenmesi, başta sağlık çalışanları olmak üzere toplumun önemli sorumluluklarından biri olarak değerlendirilmelidir. Özellikle sağlık çalışanlarının bu konuda farkındalık eğitimleri vermeleri önem arz etmektedir.

Anahtar kelimeler: Gebelik, sigara, algılanan sosyal destek, benlik saygısı, psikolojik sağlamlık 


\section{Giriş}

Gebelerin sigara kullanımı veya sigara dumanına maruz kalması, fetusa ve yenidoğana verdiği zarardan dolayı önemli bir halk sağlığı sorundur. Dünya genelinde her 4 kadından biri gebelik sırasında aktif sigara içtiği tahmin edilmektedir (1). Amerika Birleşik Devletleri'nde (ABD), gebe kadınların sigara içme oranı $\% 5,1$ ile \%28,7 arasında (genel prevalansı \%10,7) değişmektedir $(2,3)$. Türkiye'de yapılan çalışmalarda gebelik öncesi sigara içen kadınların gebelikte sigara içme oranları sırasıyla \%10,4, \%12,6, \%23,9 olarak bildirilmiştir (4-6). Gebelikte sigara içmenin olumsuz sağlık sonuçları olduğu göz önüne alındığında, gebelik sırasında sigara içme prevalansını etkileyen tıbbi olmayan faktörleri araştırmak, annelerin ve doğmamış çocukların sağlığını iyileştirmeye yönelik müdahalelerin tasarlanması için kritik bir adımdır $(7,8)$.

Çalışmalar gebelikte sigara kullanan kadınlarda; spontan abortus, prematür eylem, ablasyo plasenta görülebildiğini yenidoğanların da düşük doğum ağırlıkı bebek ve ani bebek ölümü riski ile karşı karşıya kaldığını göstermektedir (6,9-11). Gebelik döneminde psikososyal ve duygusal destek yetersizliği gebelikte ve doğum sonrasında ruhsal problemlerin oluşumunda belirleyici bir özelliğe sahiptir (9). Araştırmalarda sosyal destek sisteminin bireyin sosyolojik ve psikolojik sorunlarının çözümü, önlenmesi ve tedavisinde, zorlanmalı durumlarla başa çıkabilmesinde güçlü bir kaynak olduğunu ortaya koymuştur $(12,13)$.

Hem yurt dışındaki hem de Türkiye'deki literatür incelendiğinde, yapılan çalışmalarda çoğunlukla demografik değişkenlerle sigara içme ilişkisinin incelendiği görülmektedir $(14,15)$. Buradan hareketle, psikolojik destek, psikolojik dayanıklılık ve benlik saygısı gibi psikososyal değişkenlerle ile sigara içme arasındaki ilişkinin incelenmesi, sigara içme literatürüne yeni bir boyut kazandırabileceği gibi, gebelerin sigara içme durumları ile bu değişkenler arasındaki ilişkileri de ortaya koyabilir. Bu çalışmada, temel olarak sigara kullanımı olan gebenin algılanan psikososyal destek, psikolojik dayanıklılık ve benlik saygısı ile ilişkisini incelenmesi amaçlandı.

\section{Yöntem}

\section{Örneklem}

Bu araştırma tanımlayıcı, kesitsel tipte saha araştırmasıdır. Çalışma verileri Türkiye'nin kuzeyinde bir Kadın Doğum ve Çocuk Hastanesi polikliniğine başvuran gebelerden, 1 Temmuz 2019- 1 Mart 2020 tarihleri arasında toplanmıştır. Covid-19 pandemi süreci başladığı için çalışma sonlandııımıştır. Araştırmaya 13. Gebelik haftasını tamamlayan, okuma ve yazma bilen, 18 yaşından büyük ve çalışmaya katılımayı kabul eden 187 gebe dahil edilmiştir. Çalışmaya onam vermeyen, 18 yaşından küçük ve 13 hafta altı gebelik haftası olanlar, dışlanma kriteri olarak belirlenmiştir.

\section{İşlem}

Araştırmaya başlamadan önce Bartın Üniversitesi Sosyal ve Beşeri Bilimler Etik Kurulu'ndan izin (sayı no: 2019/150) ve Bartın İ Sağlık Müdürlüğünden yazıı izin (sayı no: 71504618-799-E.1900051498 ) alındı. Araştırmaya katıımda gönüllülük esas alındı. Araştırmaya katımaya gönüllü gebelerden aydınlatımış gönüllü olur formu ile yazılı izinleri dahilinde veriler yüz yüze görüşme tekniği ile toplandı. Kadın Doğum polikliniğine 9 ay içerisinde gelen, çalışma amacı açıklandıktan sonra çalışmayı kabul eden bütün gebeler ile soru formu yüz yüze görüşme tekniği ile dolduruldu ve uygulanması her bir gebe için ortalama 15-20 dakika sürmüştür.

\section{Veri Toplama Araçları}

Araştırmada Tanııı Bilgi Formu, Fagerström Nikotin Bağımlılık Testi (FNBT), Rosenberg Benlik Saygısı Ölçeği (RBSÖ), Çok Boyutlu Algılanan Sosyal Destek Ölçeği (ÇBASDÖ), Kısa Psikolojik Sağlamlık Ölçeği (KPS) kullanılmıştır. 


\section{Tanıtıcı Bilgi Formu}

Araştırmacılar tarafından hazırlanan gebe kadınların yaş, eğitim, gelir düzeyi, mesleği, evlilik yılı, evlenme yaşı, gebelik haftası, gebelik sayısı, aile içi şiddete maruz kalma durumu gibi tanıtıcı özellikleri ile gebelerin sigara içme davranışı ile ilgili özelliklerini sorgulayan 27 sorudan oluşan bir formdur.

\section{Fagerström Nikotin Bağımlılık Testi}

Sigara bağımlıı̆ının değerlendirilmesinde en sık kullanılan test Fagerström Nikotin Bağımlılık Testi'dir (FNBT). Illk kez 1978'de Fagerström, Fagerström Tolerans Testi'ni önermiştir. Bu test 1991'de Heatherton ve ark. tarafından yeniden ele alınmış ve FNBT ortaya çıkmıştır. Bu çalışmada da sigara bağımlılık ölçeği olarak "Fagerström Nikotin Bağımlılık Testin (FNBT)" kullanılmışı̧ı (16). FBNT’nin Türkçe versiyonu Uysal ve ark. tarafından yapılmış türkçe versiyonu orta derecede güvenilir bulunmuş (Cronbach alfa: 0.56) ve form Uysal ve arkadaşları tarafından kullanılmıştır. FNBT altı sorudan oluşmakta olup her soruya farkı puan verilmektedir. Bu testin değerlendirilmesi sonucu elde edilen toplam puanlara göre nikotin bağımlılı̆ı düşük (0-3 puan), orta (4-6 puan), yüksek ( $\geq 7$ puan) şeklinde üç grupta derecelendirilmiştir (17).

\section{Rosenberg Benlik Saygısı Ölçeği}

Rosenberg tarafından 1965 ylında geliştirilmiş, Türkiye'de güvenilirlik ve geçerlilik çalışmaları Çuhadaroğlu (1986) tarafından yapılmıştır. Ölçek çoktan seçmeli sorulardan yapılanmış 12 alt kategoride toplam 63 sorudan oluşmaktadır. Araştırmada kullanılan RBSÖ Benlik Saygısı Alt Ölçeği, 4-noktalı Likert tipi bir alt ölçek olup, envanterin ilk 10 maddesini oluşturmaktadır. Yanıtlar, cevap anahtarının öngördüğü şekilde, tekli, ikili ya da üçlü gruplara ayrılarak puanlandığından, alt ölçek toplam puan yayılım genişliği 0-6 arasındadır. Toplamda, 0-1 puan alanlar "yüksek", 2-4 puan alanlar "orta" ve 5-6 puan alanlar "düşük" benlik saygısına sahip kişiler olarak nitelendirilir. Olumlu ve olumsuz yüklü maddeler ardışık olarak sıralanır. 1. 2. 4. 6. 7. Maddeler olumlu, 3. 5. 8. 9. 10. maddeler olumsuz yüklüdür. Ölçek puanlamasında düşük puan, benlik saygısının yüksekliğini; yüksek puan, benlik saygısının düşüklüğünü gösterir $(18,19)$.

\section{Çok Boyutlu Algılanan Sosyal Destek Ölçeği}

Çok Boyutlu Algılanan Sosyal Destek Ölçeği 1988'de Zimmet ve arkadaşları tarafından geliştirilmiş, Eker ve Arkar (1995) tarafından Türkçe'ye uyarlama çalışmaları yapılmış ve 2001 yılında Eker, Arkar, Yaldız tarafından gözden geçirilmiş formunun geçerlik ve güvenirlik çalışmaları yapıımışıı. Çok Boyutlu Algılanan Sosyal Destek Ölçeği aile, arkadaş ve özel bir insan olmak üzere üç farklı kaynaktan algılanan sosyal desteğin yeterliliğinin öznel olarak değerlendirilmesini içeren 12 maddeden oluşmaktadır. Her madde 7 aralıklı likert tipi bir ölçek kullanılarak değerlendirilmektedir. Her alt ölçekteki dört maddenin puanlarının toplanması ile alt ölçek puanı elde edilmekte olup, bütün alt ölçek puanlarının toplanması ile ölçeğin toplam puanı elde edilmektedir. Elde edilen puanın yüksek olması algılanan sosyal desteğin yüksek olduğunu göstermektedir $(20,21)$.

\section{Kısa Psikolojik Sağlamlık Ölçeği}

Öğrencilerin psikolojik sağlamlık düzeylerini belirlemek amacıyla Smith ve ark. (2008) tarafından geliştirilen ve Türkçe'ye uyarlaması Doğan (2015) tarafından yapılan "Kısa Psikolojik Sağlamlık Ölçeği” kullanılmıştır. KPSÖ, 5'li likert tipinde bir dereceleme ile derecelendirilen 3 olumlu 3 olumsuz olmak üzere toplam 6 maddelik bir ölçme aracıdır. Ölçekte bulunan ve tersten kodlanan maddeler çevrildikten sonra, alınan yüksek puanlar, yüksek psikolojik sağlamlığı ifade etmektedir. Ölçeğin Türkçe formunun geçerliği kapsamında yapılan faktör analizi sonuçları toplam varyansın\% 54'ünü açıklayan tek faktörlü bir yapıda olduğunu, ölçek maddelerine ilişkin faktör yüklerinin ise, 0.63 ile 0.79 arasında değişen değerlerde olduğunu göstermiştir. KPSÖ'nün güvenirliği için hesaplana iç tutarlık katsayısı 0.83 olarak bulunmuştur. Bu çalışma için hesaplanan iç tutarlık katsayısı $\alpha=0,79$ olarak bulunmuştur $(22,23)$.

\section{Veri Analizi}

Araştırmada elde edilen veriler SPSS (Statistical Package for Social Sciences) for Windows 25.0 programı kullanılarak analiz edilmiştir. Verileri değerlendirilirken tanımlayıcı istatistiksel metotları (sayı, yüzde, 
ortalama, standart sapma, minimum ve maksimum) kullanılmıştır. Araştırmada yer alan katılımcılardan elde edilen skorların normalliği hem testler ve basıklık çarpıklık değerleri hem de görsel olarak grafikler ile incelenmiştir. Verilerin normal dağılmadığı gözlemlenmiştir. Normal dağılmadığı için ölçekler arasındaki ilişki Spearman'skorelasyon analizi ile incelenmiştir. Niceliksel iki grup karşılaştırılması için normal dağılan verilerde bağımsız örneklem t testi, normal dağılmayan verilerde Mann Whitney U testi kullanılmıştır. Niceliksel ikiden fazla grup karşılaştıııması için normal dağılan verilerde ANOVA testi, normal dağılmayan verilerde Kruskal Wallis H testi kullanılmıştır. Ölçekler arasındaki yordama ilişkisi için verilere dönüşüm uygulanmıştır. Logaritmik dönüşüm sonrasında normal dağılan veriler ile regresyon analizi yapıımıştır.

\section{Bulgular}

Araştırmaya katılan gebelerin yaş ortalaması 28,00 5,29 olarak hesaplanmıştır. Gebelerin \%97,8'inin resmi nikahlı olduğu, \%94,7'sinin sadece 1 evlilik yaptığı, \%52,4'ünün ilköğretim mezunu olduğu, \%76,5'inin çalışmadığı (ev hanımı olduğu), \%60,4'ünün gelirinin gidere denk olduğu tespit edilmiştir. Gebelik öncesinde sürekli solunum sistemi hastalığı olanların oranı \%69,5 olarak bulunmuştur. Bu gebelerin \%52,6'sı nefes darlığı, \%26,3'ü öksürük balgam, \%17,'sinin hırıltı, \%3,5'inin göğüste ağrı sorunu yaşadığını ifade etmiştir. Gebelik haftası incelendiğinde \%50,8'i üçüncü trimesterde iken \%41,7'sinin ikinci trimesterde olduğu saptanmıştır (Tablo 1).

Ölçeklerin demografik özelliklere göre karşılaştırıması için bağımsı örneklerde karşılaştırma testleri yapılmıştır. Yaşa, eğitime, mesleğe, gelir durumuna, evlilik yllına, gebelik sayısına, gebelik haftasına, göre bireylerin benlik saygısı, algıladıkları sosyal destek ve psikolojik sağlamlık skorları istatistiksel olarak anlamlı bir farklıık saptanmamıştır ( $p>0,05)$ (Tablo 1). Ancak gebelerin evlenme yaşına göre benlik algısı ve algıladıkları sosyal destek puanları arasında istatistiksel olarak anlamlı bir farklılık olduğu tespit edilmiştir $(p<0,05)$ (Tablo 1). Yaş değişkeni açısında incelendiğinde, 22 yaşından küçük bir yaşta evlenen bireylerin benlik saygısı ve algıladıkları sosyal destek puanları 23 yaşından büyük bir yaşta evlenenlere göre daha yüksek bulunmuştur. Sigaranın bebeğe zararlarını bilme durumuna göre algılanan sosyal destek puanları istatistiksel olarak anlamlı bir farkılık saptanmıştır $(p<0,05)$ (Tablo 1). Bilmeyenlerin algıladıkları sosyal destek daha yüksek bulunmuştur. Aile içi şiddet varlığına göre de algılanan sosyal destek ve benlik saygısı puanları istatistiksel olarak anlamlı bir farklılık gösterdiği tespit edilmiştir $(p<0,05)$ (Tablo 1). Aile içi şiddete maruz kalanların benlik saygısı ve algıladıkları sosyal destek puanları daha düşük bulunmuştur $(p<0,05)$ (Tablo 1).

Çalışmaya katılan gebelerin \%13'ü şu anki gebeliklerinde sigara içmektedir. Gebelerin \%34,9'ü daha önce de sigara içmiştir. Sigarayı bırakan gebelerin \%58,8'inin gebelik yüzünden sigarayı bıraktığı, \%29,4'ün diğer nedenlerden dolayı sigarayı bıraktı̆ı tespit edilmiştir. Gebelerin sigara başlama yaşı $18,74 \pm 4,06$ olarak hesaplanmıştır (Tablo 2). Gebelerin sigaraya başlama nedeni en yüksek \%33,8 çevre, \%24,6 merak

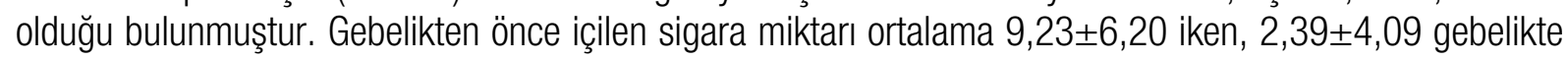
içilen sigara miktarı olarak tespit edilmiştir (Tablo 2). Gebelerin \%93,8'i eşinin sigara içtiğini bildiğini, $\% 86,2$ 'si sigarayı bırakmayı düşünmekte olduğunu ve \%58,5'i sigarayı bırakma girişiminde bulunduğunu ve \%56,9'unun girişim sonucunda sigarayı bırakamadığı tespit edilmiştir (Tablo 2). Bireylerin \%67,7'sinin eşinin sigara içmediği, \%55,3'ünün gebelikte evinde sigara kullanımının olduğu, \%41,6'sının sigara dumanına maruz kaldığı tespit edilmiştir. Maruz kalanların \%35,6'sının ev arkadaş ziyaretinde, \%25,4'ünün evde ve iş yerinde, $\% 20,3$ 'ünün kafe ve restoran gibi mekanlarda maruz kaldığı saptanmıştır (Tablo 2).

Gebelerin \%80,2'sinin sigaranın bebekler üzerindeki etkisini bildiği, \%33,7'sinin de bebeğin sağıı̆ına karşı endişe duyduğu, aile içi şiddete maruz kalmayan gebelerin oranının $\% 1,8$, sözel şiddete maruz kalan gebelerin oranının \%47,1 olduğu bulunmuştur (Tablo 2). Gebelerin "hayatınızda hiç sigara içtiniz mi" ve " gebelik öncesi sigara içtiniz mi" sorularına verdikleri cevaplara göre benlik saygısı, algıladıkları sosyal destek ve psikolojik sağlamlık ölçeklerinden aldıkları puanların istatistiksel olarak anlamlı bir farkkılık göstermediği tespit edilmiştir ( $p>0,05)$ (Tablo 3). 
Tablo 1. Gebelerin sosyodemografik özelliklerine göre Rosenberg Benlik Saygısı (RBSÖ), Algılanan Sosyal Destek (ASDÖ) ve Psikolojik Sağlamlık Ölçek (KPSÖ) puanlarının karşılaştıııması

\begin{tabular}{|c|c|c|c|c|c|c|c|c|}
\hline \multicolumn{2}{|r|}{ Ölçekler } & \multicolumn{3}{|c|}{ RBSÖ } & \multicolumn{3}{|c|}{ ASDÖ } & KPSÖ \\
\hline & & Ortalama & Min & Mak & Ortalama & Min & Mak & Ortalama \pm SS \\
\hline \multirow[t]{3}{*}{ Yaş } & $\leq 25$ & 0,91 & 0,16 & 4,01 & 41,00 & 19,00 & 93,00 & $18,74 \pm 5,07$ \\
\hline & $26-30$ & 0,91 & 0,00 & 3,24 & 41,00 & 19,00 & 93,00 & $16,85 \pm 4,56$ \\
\hline & $31+$ & 0,87 & 0,16 & 3,00 & 37,00 & 19,00 & 93,00 & $18,37 \pm 4,25$ \\
\hline \multicolumn{2}{|c|}{$\begin{array}{l}\text { Test değeri } \\
\text { p değeri }\end{array}$} & $\begin{array}{l}0,573 \\
0,751\end{array}$ & & & $\begin{array}{l}2,007 \\
0,367\end{array}$ & & & $\begin{array}{l}2,944 \\
0,055\end{array}$ \\
\hline \multirow[t]{3}{*}{ Eğitim } & İlköğretim & 0,91 & 0,16 & 3,24 & 41,00 & 19,00 & 93,00 & $17,50 \pm 4,72$ \\
\hline & Lise & 0,91 & 0,00 & 4,01 & 41,00 & 19,00 & 93,00 & $17,53 \pm 4,35$ \\
\hline & Üniversite + & 0,66 & 0,16 & 2,83 & 33,50 & 19,00 & 93,00 & $19,37 \pm 4,83$ \\
\hline \multicolumn{2}{|l|}{$\begin{array}{l}\text { Test değeri } \\
\text { p değeri }\end{array}$} & $\begin{array}{l}0,112 \\
0,738\end{array}$ & & & $\begin{array}{l}0,119 \\
0,731\end{array}$ & & & $\begin{array}{l}2,840 \\
0,061\end{array}$ \\
\hline \multirow[t]{2}{*}{ Meslek } & Ev hanımı & 0,91 & 0,00 & 4,01 & 41,00 & 19,00 & 93,00 & $17,55 \pm 4,49$ \\
\hline & Memur/Işçi/Diğer & 0,91 & 0,25 & 3,24 & 39,00 & 19,00 & 93,00 & $18,11 \pm 4,79$ \\
\hline \multicolumn{2}{|c|}{$\begin{array}{l}\text { Test değeri } \\
\text { p değeri }\end{array}$} & $\begin{array}{l}-0,036 \\
0,971\end{array}$ & & & $\begin{array}{l}-0,593 \\
0,553\end{array}$ & & & $\begin{array}{c}-0,586 \\
0,558\end{array}$ \\
\hline \multirow[t]{3}{*}{$\begin{array}{l}\text { Gelir } \\
\text { Durumu }\end{array}$} & Gelir < gider & 0,91 & 0,25 & 4,01 & 41,00 & 19,00 & 93,00 & $16,58 \pm 4,14$ \\
\hline & Gelir = gider & 0,91 & 0,00 & 2,83 & 40,00 & 19,00 & 93,00 & $18,39 \pm 4,65$ \\
\hline & Gider $>$ gider & 0,66 & 0,25 & 3,24 & 39,50 & 19,00 & 82,00 & $19,00 \pm 5,61$ \\
\hline \multicolumn{2}{|l|}{$\begin{array}{l}\text { Test değeri } \\
\text { p değeri }\end{array}$} & $\begin{array}{l}5,266 \\
0,072\end{array}$ & & & $\begin{array}{l}2,356 \\
0,308\end{array}$ & & & $\begin{array}{l}3,283 \\
0,051\end{array}$ \\
\hline \multirow[t]{3}{*}{ Evlilik Yılı } & $\leq 3$ & 0,91 & 0,16 & 4,01 & 39,00 & 19,00 & 93,00 & $17,84 \pm 4,67$ \\
\hline & $4-7$ & 0,91 & 0,25 & 2,66 & 41,00 & 19,00 & 85,00 & $17,89 \pm 4,63$ \\
\hline & $8+$ & 0,91 & 0,00 & 3,00 & 41,00 & 19,00 & 93,00 & $18,29 \pm 4,94$ \\
\hline \multicolumn{2}{|l|}{$\begin{array}{l}\text { Test değeri } \\
\text { p değeri }\end{array}$} & $\begin{array}{l}0,800 \\
0,670\end{array}$ & & & $\begin{array}{l}1,926 \\
0,382\end{array}$ & & & $\begin{array}{l}0,161 \\
0,851\end{array}$ \\
\hline \multirow[t]{2}{*}{$\begin{array}{l}\text { Evlenme } \\
\text { Yaşı }\end{array}$} & $\leq 22$ & 0,91 & 0,00 & 4,01 & 41,00 & 19,00 & 93,00 & $18,20 \pm 5,00$ \\
\hline & $23+$ & 0,67 & 0,16 & 2,83 & 37,00 & 19,00 & 93,00 & $17,69 \pm 4,30$ \\
\hline \multicolumn{2}{|l|}{$\begin{array}{l}\text { Test değeri } \\
\text { p değeri }\end{array}$} & $\begin{array}{l}-2,196 \\
0,028\end{array}$ & & & $\begin{array}{c}-2,176 \\
0,030\end{array}$ & & & $\begin{array}{l}0,726 \\
0,469\end{array}$ \\
\hline \multirow[t]{3}{*}{$\begin{array}{l}\text { Gebelik } \\
\text { sayısı }\end{array}$} & 1 & 0,87 & 0,16 & 4,01 & 38,50 & 19,00 & 93,00 & $18,33 \pm 4,77$ \\
\hline & 2 & 0,91 & 0,16 & 3,24 & 41,00 & 19,00 & 93,00 & $17,48 \pm 4,66$ \\
\hline & $3+$ & 0,91 & 0,00 & 3,00 & 41,00 & 19,00 & 93,00 & $18,05 \pm 4,74$ \\
\hline \multicolumn{2}{|c|}{$\begin{array}{l}\text { Test değeri } \\
\text { p değeri }\end{array}$} & $\begin{array}{l}0,440 \\
0,802\end{array}$ & & & $\begin{array}{l}3,082 \\
0,214\end{array}$ & & & $\begin{array}{l}0,517 \\
0,597\end{array}$ \\
\hline \multirow{3}{*}{$\begin{array}{l}\text { Gebelik } \\
\text { Dönemi }\end{array}$} & 1.trimester & 0,74 & 0,00 & 2,66 & 44,00 & 23,00 & 82,00 & $18,28 \pm 4,33$ \\
\hline & 2.trimester & 0,90 & 0,16 & 4,01 & 38,00 & 19,00 & 93,00 & $18,20 \pm 5,22$ \\
\hline & 3.trimester & 0,91 & 0,16 & 3,24 & 41,00 & 19,00 & 93,00 & $17,76 \pm 4,35$ \\
\hline \multicolumn{2}{|c|}{$\begin{array}{l}\text { Test değeri } \\
\text { p değeri }\end{array}$} & $\begin{array}{l}1,186 \\
0,553\end{array}$ & & & $\begin{array}{l}4,012 \\
0,135\end{array}$ & & & $\begin{array}{l}0,211 \\
0,810\end{array}$ \\
\hline \multirow[t]{2}{*}{ Bilgi } & Hayır & 0,91 & 0,00 & 2,08 & 45,00 & 21,00 & 93,00 & $17,92 \pm 4,22$ \\
\hline & Evet & 0,91 & 0,16 & 4,01 & 39,50 & 19,000 & 19,00 & $18,00 \pm 4,84$ \\
\hline $\begin{array}{l}\text { Test } \\
\text { değeri } \\
\text { p değeri }\end{array}$ & & $\begin{array}{l}-0,636 \\
0,525\end{array}$ & & & $\begin{array}{l}-1,990 \\
0,047\end{array}$ & & & $\begin{array}{c}-0,101 \\
0,920\end{array}$ \\
\hline \multirow[t]{2}{*}{$\begin{array}{l}\text { Aile içi } \\
\text { şiddete } \\
\text { maruz } \\
\text { kalma }\end{array}$} & Hayır & 0,91 & 0,00 & 3,00 & 37,00 & 19,00 & 93,00 & $18,20 \pm 4,93$ \\
\hline & Evet & 1,12 & 0,25 & 4,01 & 57,50 & 29,00 & 93,00 & $17,00 \pm 3,49$ \\
\hline \multicolumn{2}{|l|}{$\begin{array}{l}\text { Test değeri } \\
\text { p değeri }\end{array}$} & $\begin{array}{l}-2,131 \\
0,033\end{array}$ & & & $\begin{array}{l}5,559 \\
0,000\end{array}$ & & & $\begin{array}{l}1,354 \\
0,177\end{array}$ \\
\hline
\end{tabular}


Tablo 2. Gebelerin sigara içme davranışı ile ilgili özellikleri

\begin{tabular}{|c|c|c|c|}
\hline Özellikler & Ortalama \pm SS & $n$ & $\%$ \\
\hline Sigaraya başlama yaşı & $18,78 \pm 4,06$ & & \\
\hline Gebelikten önce sigara miktarı & $9,23 \pm 6,20$ & & \\
\hline Gebelikte sigara miktarı & $2,39 \pm 4,09$ & & \\
\hline \multirow[t]{2}{*}{ Hayatınızda hiç sigara içtiniz mi? } & Hayır & 122 & 65,2 \\
\hline & Evet & 65 & 34,8 \\
\hline \multirow[t]{2}{*}{ Hala sigara içme durumu } & Hayır & 163 & 87.0 \\
\hline & Evet & 24 & 13.0 \\
\hline \multirow[t]{4}{*}{ Sigaraya başlama nedeni } & Merak & 16 & 24,6 \\
\hline & Özenti & 9 & 13,8 \\
\hline & Çevre & 22 & 33,8 \\
\hline & Diğer & 18 & 27.7 \\
\hline \multirow[t]{2}{*}{ Sigarayı bırakmayı düşünme durumu } & Hayır & 9 & 13,8 \\
\hline & Evet & 56 & 86,2 \\
\hline \multirow[t]{2}{*}{ Sigara bırakma girişiminde bulunma } & Hayır & 27 & 40,5 \\
\hline & Evet & 38 & 58,5 \\
\hline \multirow[t]{2}{*}{ Girişimin sonucu } & Bıraktım & 29 & 43,1 \\
\hline & Bırakamadım & 37 & 56,9 \\
\hline \multirow[t]{3}{*}{ Sigarayı bırakma nedeni } & Gebelikte planladığım için & 6 & 11,8 \\
\hline & Gebe kaldığım için & 30 & 58,8 \\
\hline & Diğer & 15 & 29,4 \\
\hline \multirow[t]{2}{*}{ Daha önceki gebeliklerde sigara içme } & Hayır & 43 & 66,2 \\
\hline & Evet & 22 & 33,8 \\
\hline \multirow[t]{2}{*}{ Eşin sigara kullanma durumu } & Hayır & 30 & 32,3 \\
\hline & Evet & 63 & 67,7 \\
\hline \multirow[t]{2}{*}{ Gebelikte evde sigara kullanma durumu } & Hayır & 40 & 44,7 \\
\hline & Evet & 50 & 55,3 \\
\hline \multirow[t]{2}{*}{ Sigara durumuna maruz kalma } & Hayır & 59 & 58,4 \\
\hline & Evet & 42 & 41,6 \\
\hline \multirow[t]{4}{*}{ Nerede maruz kalıyorsunuz } & Evde ve iş yerinde & 15 & 25,4 \\
\hline & Ev arkadaş ziyareti & 21 & 35,6 \\
\hline & Kafe restoran & 12 & 20,3 \\
\hline & Diğer & 11 & 18,6 \\
\hline \multirow[t]{4}{*}{ Evde sigara içilen yer } & İçilmez & 22 & 23,17 \\
\hline & Balkon & 52 & 53,87 \\
\hline & Sigara odası & 4 & 4,87 \\
\hline & Diğer & 17 & 18,08 \\
\hline \multirow[t]{2}{*}{ Sigaranın bebekler üzerindeki etkilerin, bilme durumu } & Hayır & 37 & 19,8 \\
\hline & Evet & 150 & 80,2 \\
\hline \multirow[t]{4}{*}{ Bebeğin sağlı̆ı̆ına karşı endişelenme } & Endişelenmiyor & 54 & 28,9 \\
\hline & Biraz endişeleniyor & 47 & 25,1 \\
\hline & Endişeleniyor & 63 & 33,7 \\
\hline & Çok endişeleniyor & 23 & 12,3 \\
\hline \multirow[t]{2}{*}{ Aile içi şiddet durumu } & Hayır & 153 & 91,8 \\
\hline & Evet & 34 & 18,2 \\
\hline \multirow[t]{4}{*}{ Şiddet türü } & Fiziksel şiddet & 1 & 2,9 \\
\hline & Sözel şiddet & 16 & 47,1 \\
\hline & Cinsel şiddet & 2 & 5,9 \\
\hline & Duygusal şiddet & 15 & 44,1 \\
\hline
\end{tabular}

Gebelerin algıladığı sosyal destek ile benlik saygısı arasında istatistiksel olarak anlamlı, pozitif yönlü ve zayıf düzey bir ilişki olduğu tespit edilmiştir ( $p<0,01: r=0,208)$. Bireylerin nikotin bağımlılık düzeyleri ile benlik 
saygısı arasında istatistiksel olarak anlamlı, pozitif yönlü ve orta düzey bir ilişki olduğu bulunmuştur $(p<0,01: r=0,413)$ (Tablo 4).

Tablo 3. Gebelerin sigara içme durumlarına göre Rosenberg Benlik Saygısı (RBSÖ), Algılanan Sosyal Destek (ASDÖ)ve Kısa Psikolojik Sağlamlık (KPSÖ) ölçek puanlarının karşılaştıııması

\begin{tabular}{|c|c|c|c|c|c|c|c|c|}
\hline \multirow[t]{2}{*}{ Sigara İçme } & Ölçekler & RBSÖ & & \multicolumn{3}{|c|}{ ASDÖ } & \multicolumn{2}{|r|}{ KPSÖ } \\
\hline & & Med & Min & Mak & Med & Min & Mak & Ortalama \pm SS \\
\hline $\mathrm{S} 1^{*}$ & Hayır & 0,91 & 0,00 & 3,24 & 41,00 & 19,00 & 93,00 & $17,87 \pm 4,69$ \\
\hline & Evet & 0,91 & 0,16 & 4,01 & 38,00 & 19,00 & 93,00 & $18,22 \pm 4,79$ \\
\hline $\begin{array}{l}\text { Test değeri } \\
\text { p değeri }\end{array}$ & & $\begin{array}{l}-0,338 \\
0,735\end{array}$ & & & $\begin{array}{l}-0,564 \\
0,573\end{array}$ & & & $\begin{array}{r}-0,477 \\
0,634\end{array}$ \\
\hline & & Med & Min & Mak & Ortalama \pm SS & & & Ortalama \pm SS \\
\hline$S 2^{* *}$ & Hayır & 0,75 & 0,16 & 2,75 & $37,13 \pm 13,22$ & & & $18,81 \pm 5,14$ \\
\hline & Evet & 0,91 & 0,16 & 4,01 & $44,08 \pm 20,66$ & & & $18,02 \pm 4,71$ \\
\hline $\begin{array}{l}\text { Test değeri } \\
\text { p değeri }\end{array}$ & & $\begin{array}{c}-0,596 \\
0,551\end{array}$ & & & $\begin{array}{c}-1,261 \\
0,212\end{array}$ & & & $\begin{array}{l}0,571 \\
0,570\end{array}$ \\
\hline
\end{tabular}

*S1: hayatınızda hiç sigara içtiniz mi?, ${ }^{\star \star}$ S2: gebelik öncesi sigara içtiniz mi?

Gebelerin bağımlıık düzeyleri ve algıladıkları sosyal destek skorlarının gebelerin benlik saygısını yordama düzeyi incelendiğinde modelin istatistiksel olarak anlamlı olduğu görülmektedir ( $F=5,825 ; p<0,05)$ (Tablo 5). Ancak modelde kullanılan değişkenlerin anlamlııkları incelendiğinde sadece nikotin bağımlıı̆ının istatistiksel olarak anlamlı olduğu tespit edilmiştir $(p<0,05)$ (Tablo 5). Modelde çoklu doğrusal bağlantı sorunu yoktur (VIF<10). Ayrıca hatalar arasındaki ilişkinin bir ölçüsü olan DW istatistiği incelendiğince oto korelasyon yoktur ( $D W=1,918)$. Bağımsı değişkenlerin bağımlı değişkeni açıklama gücü olan adjusted R2 0,250 olarak hesaplanmıştır (Tablo 5).

Tablo 4. Sigara içen gebelerin Rosenberg Benlik Saygısı (RBSÖ), Algılanan Sosyal Destek (ASDÖ)ve Kısa Psikolojik Sağlamlık (KPSÖ) ölçek puanları arasındaki ilişki

\begin{tabular}{|l|l|c|c|c|}
\hline Ölçekler & R & $-0,063$ & KPSÖ & ASDÖ \\
\hline KPSÖ & $p$ & 0,392 & & \\
\hline & r & $0,208^{\star \star}$ & $-0,107$ & \\
\hline ASDÖ & $p$ & 0,004 & 0,145 & \\
\hline FNBT & r & $0,413^{\star \star}$ & 0,196 & 0,139 \\
\hline & $p$ & 0,008 & 0,226 & 0,391 \\
\hline
\end{tabular}

FNBT: Fagerström Nikotin Bağımlılık Testi

Tablo 5. Sigara içen gebelerin Rosenberg Benlik Saygısı (RBSÖ), Algılanan Sosyal Destek (ASDÖ) ve Kısa Psikolojik Sağlamlık (KPSÖ) ölçeklerinin regresyon analizi sonuçları

\begin{tabular}{|l|l|l|l|l|l|l|l|l|}
\hline $\begin{array}{l}\text { Bağımsız } \\
\text { Değişken }\end{array}$ & Beta & $\mathrm{m}$ & $\mathrm{p}$ değeri & Adj. R2 & VIF & $\mathrm{F}$ & $\mathrm{p}$ değeri & DW \\
\hline Sabit & $-1,863$ & $-1,813$ & 0,081 & 0,250 & 1,018 & 5,825 & 0,008 & 1,918 \\
\hline ASDÖ & 0,345 & 1,282 & 0,211 & & & & & \\
\hline FNBT & 0,541 & 2,968 & 0,006 & & & & & \\
\hline
\end{tabular}

FNBT: Fagerström Nikotin Bağımlılık Testi

\section{Tartışma}

Çalışmada, sigara kullanımı olan gebelerin algılanan psikososyal destek, psikolojik sağlamlık ve benlik saygısı ile ilişkisi incelenmiştir. Literatür, algılanan sosyal destek, psikolojik sağlamlık, benlik saygısı gibi psikolojik faktörlerin bir başa çıkma mekanizması olarak kabul edilen sigara içme davranışında önemli bir rol oynayabileceğinin altını çizmektedir. Ayrıca kişilik özellikleri de sigara içme davranışında önemli rol oynamaktadır. 
Güncel çalışmalar incelendiğinde gebelikte sigara kullanım sıkı̆̆ının halen yüksek olduğu gözlenmiştir (24). Erzurum il merkezinde yapılan bir çalışmada ise gebe kadınlarda sigara kullanma oranı \%6,6 olarak tespit edilmiştir (25). Türkiye'de gebelikte sigara içimi ile ilgili yapılan çalışmalar incelendiğinde, oranlardaki farklılıkar dikkati çekmektedir. Gebelerde sigara içme oranları Sivas'ta 2003 yllında yapılan bir çalışmada \%17, Sakarya'da 2006 ylında \%12,7, Konya'da 2007 yllında \%7,3, Manisa'da 2009 ylında \%19,1 olarak bulunmuştur (26-28). Amerika'da yapılan bir meta-analize göre gebelik sırasında sigara içme oranı \%12,2 ve çeşitli Avrupa ülkelerinde yapılan diğer bir meta-analize göre ise \%13,3'tür (29). Türkiye Nüfus ve Sağlık Araştırması (TNSA) 2003'e göre gebelikte sigara içme prevalansı \%15 ve 2008'de \%11,4'tür (30,31).

Türkiye'deki diğer araştırmalarda gebelikte sigara içme davranışını etkileyen esas faktörler düşük doğum yaşı, düşük sosyoekonomik düzey, çocuk sayısının fazla olması ve sigara içen bireylerle aynı evde yaşamaktır (5). Çalışmamızdaki gebelerin psikososyal olumsuzlukları; \%52,4'sinin eğitim düzeyinin ilköğretim olması, \%76,5'nin çalışmıyor olması, \%60,4'ünün gelirinin gidere denk olması olarak bulunmuştur. Benzer şekilde 2011 yllında yapılan bir çalışma ise gebelik sırasında sigara içen kadınların sigara içmeyen kadınlara göre daha olumsuz psikososyal zorluklar kümesi yaşadıklarını göstermiştir. Ayrıca bu kadınların psikososyal açıdan güçlü ve zayıf yönlerine dikkat edilmesinin önemli olduğu vurgulanmıştır. (32). Çalışmamız sonuçlarını destekleyen bir çalışma da 2010-2017 yılları arasında Birleşik Devletler'de yapılan gebelerde sigara içme eğilimlerinin incelendiği bir çalışmadır. Birleşik Devletler'de yapılan bu çalışmada, gebelikte sigara içiminin prevalansı düşüşte ancak daha genç kadınlarda (20-24 yaş), lise ya da genel eğitsel gelişim diploması olanlarda en yüksek seviyede tespit edilmiş̧ir. Ayrıca, daha düşük seviyede eğitim gören kadınlarda prevalansın yükselmekte olduğu bulunmuştur (33).

2012 yılında roman gebe sigara kullanan kadınlardaki bir çalışmada ise sosyal destek eksikliği ve sosyoekonomik statü nikotin bağımlılığı arasında ilişki olmadığı yönünde sonuçlar elde edilmiş ve nikotin bağımlısı gebe sigara içenler için psikososyal bileşenler dâhil olduğu özel ve yoğun çabalar gerekebileceği vurgulanmıştır (34). Almanya'da yapılan bir çalışmada Elsenbruch ve arkadaşları düşük sosyal desteğe sahip kadınların gebeliğin ilk trimesterinde sigara içme olasılığının, yüksek sosyal desteğe sahip kadınlara kıyasla daha yüksek olduğunu bildirmişlerdir (35). Gebelik kadınların deneyimlerini paylaştıkları ve sıkıntı yaşadıklarında ağlarından destek aradıkları veya destek aldıkları bir zamandır. Sosyal desteğin gebelik sırasında sigara içme üzerindeki etkisini inceleyen çok az çalışma mevcuttur. Saba ve ark'nın 2014'deki çalışması gebelerde sosyal destek ve sigara kullanımı arasında istatistiksel olarak anlamlı bir ilişki olduğunu bildirmiş ve bu ilişkinin ırksal farklılıkların bir fonksiyonu olarak değişebileceğini göstermiştir (36).

Sigara içen gebelerde benlik saygısı, psikolojik sıkıntı, anksiyete, depresif belirtiler ve başa çıkma biçimleri arasındaki ilişkileri incelemek için Fransa/Paris'te yapılan bir kesitsel çalışmada sigara içen gebe kadın grubunun, sigara içmeyen gebe gruba göre anlamlı olarak daha düşük ortalama benlik saygısı, yüksek psikolojik sıkıntı ve anksiyete puanlarına sahip olduğu ve daha fazla duygu odaklı başa çıkma kullandıkları tespit edilmiştir (37). Bizim çalışmamızda da bu bulguları destekler şekilde gebelerin algıladığı sosyal destek ile benlik saygısı arasında istatistiksel olarak anlamlı, pozitif yönlü ve zayıf düzey bir ilişki olduğu tespit edilmiştir. Bireylerin nikotin bağımlıık düzeyleri ile benlik saygısı arasında istatistiksel olarak anlamlı, pozitif yönlü ve orta düzey bir ilişki olduğu bulunmuştur.

Bu araştırma verileri 1 Temmuz 2019- 1 Mart 2020 tarihleri arasında bir Kadın Doğum ve Çocuk Hastanesi polikliniğine başvuran gebelerle sınırlıdır. Araştırma bulguları tüm gebelere genellenemez. Türkiye'nin farklı bölgelerinde daha geniş örneklem ile gerçekleştirilecek çalışmalar yapılması önerilebilir.

Sonuç olarak, bu çalışma, gebelere sigarayı bırakmaları yönünde daha spesifik destek sağlamak için psikolojik değişkenleri değerlendirmenin önemini doğrulamaktadır. Sigara bağımlılığın gelecek nesillere aktarıması gibi olasıııklar da göz önüne alındığında, sigara kullanımının ve pasif içiciliğin bütün bireylerde özellikle de anne adaylarında önlenmesi, başta sağlık çalışanları olmak üzere toplumun önemli sorumluluklarından biri olarak değerlendirilmelidir. Özellikle sağlık çalışanlarının bu konuda farkındalık eğitimleri vermeleri önem arz etmektedir. 


\section{Bağımlılık Dergisi - Journal of Dependence}

\section{Kaynaklar}

1. Fenercioğlu AK, Yıldırım G, Karatekin G, Göker N. The relationship of gestational smoking with pregnancy complications and sociodemographic characteristics of mothers. J Turkish-German Gynecol Assoc 2009; 10(3): 148-151.

2. Tong VT, Dietz PM, Farr SL, et al. England Estimates of smoking before and during pregnancy, and smoking cessation during pregnancy: comparing two population-based data sources Public Health Rep 2013; 128(3): 179-188.

3. Doogan NJ, Roberts ME, Wewers ME, et al. A growing geographic disparity: ruraland urban cigarette smoking trends in the United States. Prev Med 2017; 104: 79-85.

4. Mutlu LC, Varol Saraçoğlu G. Prevalence of smoking and factors affecting smoking behaviour during pregnancy: A sample from Tekirdağ. Türkiye Halk Sağlığı Dergisi 2014; 12(1): 1-12.

5. Ergin A, Erken RR, Til AA, Kasal H. Smoking behaviors of mothers during pregnancy and postpartum in a semiruralarea. Türk Aile Hekimliği Dergisi 2020; 24(1): 23-31.

6. Durualp E, Bektaș G, Ergin Karaca D, Topçu E. Annelerinin sigara kullanımı ile yeni- doğanın doğum kilosu, boyu ve başçevresi arasındaki ilişkinin incelenmesi. Ankara Üniversitesi Tıp Fakültesi Mecmuası 2011; 64(3): 119126.

7. Alberg AJ, Shopland DR, Cummings KM. The 2014 Surgeon General's report: commemorating the 50th Anniversary of the 1964 Report of the Advisory Committee to the US Surgeon General and updating thee vidence on the health consequences of cigarette smoking. Am J Epidemiol 2014; 179(4): 403-412.

8. Galiatsatos P, Brigham E, Krasnoff R, et al. Association between neighborhood socioeconomic status, tobacco store density and smoking status in pregnant women in an urban area. Prev Med 2020; 136: 106-107.

9. Nakamura MU, Alexandre SM, Kuhndos Santos JF, et al. Obstetric and perinatal effects of active and/or passive smoking during pregnancy. Sao Paulo Med J 2004; 122(3): 94-98.

10. Atalay S, Dağhan Ş, Kalkım A. Gebelerin pasif içiciliğin fetüs ve yenidoğan sağlığına etkileri konusundaki bilgileri. Sürekli Tıp Ĕgitimi Dergisi 2014; 23(1): 16-24.

11. Kurtuluş Ş, Can R, Sak ZHA. Assessment of the relationship between smoking and depression in pregnant women. J Immigrant Minority Health 2020; doi: 10.1007/s10903-020-01044-z.

12. Cohen S. Social relationships and health. Am Psychol 2004; 59(8): 676-684.

13. Kaziasty K. Social support and traumatic stres. The National Center for Post Traumatic Stress Disorder Research Quarterly 2005; 16(2):1-8.

14. Wesołowska $E$, Jankowska A, Trafalska $E$, et al. Sociodemographic, lifestyle, environmental and pregnancyrelated determinants of dietary patterns during pregnancy. Int J Environ Res Public Health 2019; 16(5): 754.

15. Houston-Ludlam AN, Bucholz KK, Grant JD, et al. The interaction of sociodemographic risk factors and measures of nicotine dependence in predicting maternal smoking during pregnancy. Drug Alcohol Depend 2019; 198: 168-175.

16. Heatherton TF, Kozlowski LT, Frecker RC, Fagerström KO. The Fagerström Test for Nicotine Dependence: a revision of the Fagerström Tolerance Questionnaire. Br J Addict 1991; 86: 1119-1127.

17. Uysal MA, Kadakal F, Karşidağ $C$, et al. Fagerström test for nicotine dependence: reliability in a Turkish sample and factor analysis. Tuberk Toraks 2004; 52: 115-121.

18. Rosenberg M. Society and the Adolescent Self-Image. Princeton, NJ: Princeton University Pres; 1965.

19. Çuhadaroğlu F. Adolesanlarda benlik saygısı. Uzmanlık Tezi, Hacettepe Üniversitesi Tıp Fakültesi, Ankara, 1986.

20. Zimet GD, Dahlem NW, Zimet SG, et al. The Multidimensional Scale of Perceived Social Support. J Pers Assess 1988; 52: 30-41.

21. Eker D, Arkar H, Yaldız H. Çok Boyutlu Algılanan Sosyal Destek Ölçeğinin gözden geçirilmiş formunun faktör yapısı, geçerlik ve güvenirliği. Turk Psikiyatri Derg 2001; 12(1): 17-25.

22. Smith BW, Dalen J, Wiggins K, et al. The brief resilience scale: Assessing the ability to bounce back. Int J Behav Med 2008; 15: 194-200.

23. Doğan T. Kısa Psikolojik Sağlamlık Ölçeği'nin Türkçe uyarlaması: Geçerlik ve güvenirlik çalışması. Journal of Happiness \& Well-Being 2015; 3(1): 93-102.

24. Bal Erbaş G, Şengezer T, Yılıırım U, Özkara A. Ankara'da Bir kadın doğum hastanesine başvuran gebelerde sigara kullanımı ve sigara dumanından pasif etkilenme durumlarının araştıııması. Konuralp Tıp Dergisi 2020; 12(2): 261-269.

25. Calikoglu EO, Akcay HB, Kavuncuoglu D, et al. Socio-demographic characteristics and quality of life among women in the 3rd trimester of pregnancy living in Erzurum city center. Fam Pract Palliat Care 2018; 3: 33-38. 


\section{Bağımlılık Dergisi - Journal of Dependence}

26. Marakoğlu K, Sezer RE. Sivas'ta gebelikte sigara kullanımı. Cumhuriyet Üniversitesi Tıp Fakültesi Dergisi 2003; 25: $157-164$.

27. Marakoğlu K, Erdem D. Konya'da gebe kadınların sigara içme konusundaki tutum ve davranışları. Erciyes Tıp Dergisi 2007; 29: 47-55.

28. Altıparmak S, Altıparmak 0 , Avcı HD. Manisa'da gebelikte sigara kullanımı; yarı kentsel alan örneği. Turk Toraks Dergisi 2009; 10: 20-25.

29. Schneider S, Schütz J. Who smokes during pregnancy? A systematic literature review of population-based surveys conducted in developed countries between 1997 and 2006. Eur J Contracept Reprod Health Care 2008; 13(2): 138-147.

30. TNSA. Türkiye Nüfus ve Sağlık Araştırması 2003. Ankara: Hacettepe Üniversitesi Nüfus Etütleri Enstitüsü, 2003.

31. TNSA. Türkiye Nüfus ve Sağlık Araştırması. Ankara: Hacettepe Üniversitesi Nüfus Etütleri Enstitüsü, 2008.

32. Maxson PJ, Edwards SE, Ingram A, Miranda ML. Psychosocial differences between smokers and non-smokers during pregnancy. Addict Behav 2012; 37(2): 153-159.

33. Azagba S, Manzione $\mathrm{L}$, Shan $\mathrm{L}$, et al. Trends in smoking during pregnancy by socioeconomic characteristics in the United States, 2010-2017. BMC Pregnancy Childbirth 2020; 20: 52.

34. Meghea $\mathrm{Cl}$, Rus IA, Rus D. Risk factors associated with nicotine dependence in a sample of Romanian pregnant smokers. Eur J Obstet Gynecol Reprod Biol 2012; 163(1): 22-26.

35. Elsenbruch $\mathrm{S}$, Benson $\mathrm{S}$, Rücke $\mathrm{M}$, et al. Social support during pregnancy: effects on maternal depressive symptoms, smoking and pregnancy outcome. Hum Reprod 2007;22: 869-877.

36. Masho SW, Do E, Adekoya, S. Social support and smoking during pregnancy. J Womens Health Care 2014; 3: 1000179.

37. Varescon I, Leignel S, Gérard C, et al. Self-esteem, psychological distress, and coping styles in pregnant smokers and non-smokers.Psychol Rep 2013; 113(3): 935-947. 